Uşak Üniversitesi Sosyal Bilimler Dergisi

$2015,8 / 4$

\title{
Sosyal Bilgiler Dersi Öğretmenlerinin Tarih Konularının Öğretimine İlişkin Değer Kazanımı İle Öğretim Programı Hakkındaki Görüşlerinin Belirlenmesi* $^{*}$
}

Ali Ramazan ER ${ }^{* *}$

Nida BAYINDIR ${ }^{* * *}$

\section{Öz}

Araştırmanın amacı, sosyal bilgiler dersi kapsamında tarih konularının öğretimine ilişkin öğretmenlerin toplumsal ihtiyaçları karşılama düzeyi/değer kazanımı ile öğretim programı hakkında görüşlerini belirlemektir. Araştırma, nicel ve nitel araştırma yöntemlerinin bir arada kullanıldığı karma yöntem ile gerçekleştirilmiştir. Bu araştırmada değer kazanımı ile öğretim programı boyutları ele alınmıştır Birinci boyutla ilgili ölçekte toplam 10 adet soru yer alırken (Cronbach Alpha=0.87), ikinci boyutla ilgili, ölçekte ise, 7 adet soru yer almaktadır (Cronbach Alpha=0.66). Ayrıca bu boyutlarla ilgili öğretmenler arasından seçilen 16 kişilik bir grupla da yarı yapılandırılmış mülakat yapılmıştır. Araştırmanın evreni, 2014-2015 eğitim öğretim yılında İzmir ilinde 502 devlet ortaokulunda görev yapan 1132 sosyal bilgiler öğretmeni iken örneklemi, 80 okulda görev yapan 303 sosyal bilgiler öğretmenidir. Araştırmada değer eğitimine ilişkin sorulara verilen cevaplarda hizmet içi eğitimlere katılanlar yönünde ve meslek tecrübesi (çalışma yılı) fazla olanlar yönünde anlamlı bir farklılık olduğu belirlenirken mezun oldukları bölüme göre anlamlı bir farklılık olmadığı belirlenmiştir. Öğretim programına ilişkin sorulara verilen cevaplarda ise, öğretmenlerin mezun oldukları bölüme göre anlamlı bir farklılık olduğu belirlenirken hizmet içi kursa katılıp katılmamasına ve mesleki tecrübelerine göre anlamlı bir farklılığın olmadığı belirlenmiştir. Öğretim programıla ilgili öğretmenler 7. sinıflarda konu bütünlüğünün olmadığı ve konuların çocukların seviyesine uygun olmadığını, 8. sınıflarda ise, mevcut ders saati ile inkılap tarihi konuları yetişmediği için hızlı geçildiğini, genel olarak programın yoğun olmasına karşın ders saatinin yetersiz olduğunu

* Bu makale, "Sosyal Bilgiler Dersi Kapsamında Öğretmenlerin Tarih Konularının Öğretimine İlişkin Görüşlerinin Belirlenmesi" adlı doktora tezinden elde edilmiştir.

${ }^{* *}$ Öğretmen

*** Doç. Dr., Dumlupınar Üniversitesi Eğitin Fakültesi 
belirtmişlerdir. Buna göre, sosyal bilgiler dersi öğretim programının yeniden gözden geçirilmesi gerekmektedir.

Anahtar Kelimeler: Sosyal Bilgiler Öğretimi, Tarih Öğretimi, Değer Eğitimi, Öğretim Programı ve Öğretmen Görüşleri.

\title{
Determining the Opinions of Teachers Regarding to Teaching History Subjects in the Context of Social Studies
}

\begin{abstract}
This study aims to determine the opinions of teachers regarding to values education through teaching history subjects in the context of social study. Combining by qualitative and quantitative methods a mixed model was utilized for this study. In this concept of the study, there are the dimensions of value education and teaching program were explained. Three are mainly two dimensions constituted by the factors of value education. The first dimension contains 10 questions with a 0.87 Cronbach Alpha level. The second dimensions includes 7 questions with a 0.66 Cronbach Alpha level. The sample of the study (303 teachers) was randomly selected from total 1132 social study teachers on duty in 2014-2015 education year at 502 state schools in İzmir province. First, a questionnaire has been developed to collect data about the opinions of the teachers. The sample of the study is selected from the teacher who are serving in İzmir province by using cluster sampling and random sampling techniques. A total of 303 teachers were surveyed, and their answers were collected by using a 5 level Likert scale. In addition, in depth interviews with 16 teachers were carried out to collect detailed information about their opinions. All the data collected by qualitative and quantitative methods were analyzed by appropriate statistical methods. The findings indicated that there are statistically significant difference between the teachers based on their attendance to the in service training courses and their working year (experience). On the contrary, their major field the graduated from university did not have any significant effect on their opinions. The major field that the teachers were graduated have a significant relationship with their opinions on the curriculum. However, no significant relationship between in-service training attendance and experience on their opinions on curriculum. Regarding to curriculum the teachers mentioned that for the $7^{\text {th }}$ classes there is not a unity between the topics of the program and the course program is not suitable for the level of the students. For $8^{\text {th }}$ classes the main problem mentioned by the teachers is timing for the course. Because of the heavy schedule, the teachers said they are skipping some topics during the semester. Based on the
\end{abstract}


findings of the study several suggestions and policy implications recommendations were put forward to improve the concept of the course value education.

Keywords: Teaching Social Study, Teaching History, Values Education, Curriculum and Teacher Opinions.

\section{Giriş}

Eğitim hayat boyu devam eden ve bireyin gelişimine, ihtiyaçlarına bağlı olarak değişim gösteren bir süreçtir. Günümüzde eğitimin bilgi edinme, sosyalleşme ve meslek edinme açısından en önemli görevi üstlendiği anlaşılmaktadır. Türkiye'de de son yıllarda eğitim sisteminde etraflı bir reform çalışması içine girilmiştir. Bu bağlamda iyileştirme ve geliştirme çalışması yapılan derslerden biri de sosyal bilgiler dersidir.

\section{Sosyal Bilgiler Dersi ve Tarih Öğretimi}

Sosyal bilgiler dersi, mihver ders olarak kabul edilen derslerden biridir. Öğrencilerin yaşadıkları toplum ve toplumsal sorunlarla ilgili bilgi sahibi ve çözüm yeteneğine sahip olabilmeleri, bunu başarırken de iyi bir vatandaş olma özelliğini korumalarının yolları bu dersin konusu içine girer (Yanpar, 1997).

"Sosyal bilgiler, insanın sosyal ve fiziki çevresiyle etkileşiminin geçmiş, bugün ve gelecek bağlamında incelendiği; toplu öğretim anlayışından hareketle oluşturulmuş bir ilköğretim dersidir" (Milli Eğitim Bakanlığ1, 2006: 734). Erden (1996: 8) ise, sosyal bilgileri, "İlköğretim okullarında, sosyal bilimler disiplinlerinden seçilmiş bilgilere dayanarak, etkili ve bilinçli yurttaş yetiştirmek için, bireylere sosyal yaşama dair temel bilgi, beceri, değer ve tutumların öğretildiği bir çalışma alanı" şeklinde tanımlamıştır.

Sosyal bilgiler dersi amaç olarak öğrencilerin etkin bir yurttaş ve birey olması için gereken bilgi, beceri ve donanımı kazandırması açısından geleceğin inşası adına önemli bir yere sahiptir. Özellikle sosyal bilgiler dersi kapsamında tarih konularının öğretimi öğrencilerde geçmişi sorgulayarak günümüzü doğru okuyabilme becerileri kazandırır.

Sosyal bilgileri dersini oluşturan farklı bilim alanları içinde tarih konuları önemli yere sahiptir. Tarih sosyal bilimlerin temel disiplini durumundadır ve ulusların yaşamında tarih öğretiminin önemi büyüktür.

Zaman içinde insanın hikâyesini anlatan tarih; geçmişten günümüze bireyden topluma, ulusaldan evrensele uzanan tüm bilgileri kapsadığı gibi, 
aynı zamanda günümüzün bilimi olarak da tarif edilmektedir (Farmer ve Knight, 1995).

Tarih öğretimi öğrencilerin demokratik, analitik ve eleştirel düşünme gibi bilişsel becerilerini geliştirir. Bu derste devlet, bayrak, vatan, millet, yönetim şekli, hak ve sorumluluklar gibi kavramların öğretilmesi ile öğrencilerde yurttaşlık bilinci oluşur. Bunun yanı sıra tarih öğretimi değerlerin öğretilmesi ve yeni değerlerin kavratılmasında da önemli bir yere sahiptir. Yeni oluşturulan değerlerin içeriği bireysel, ulusal veya evrensel olabilir (Vedder ve Veugelers, 2003). Günümüzde tarih öğretimi ağırlıklı olarak zihinsel becerileri geliştirme görevi yüklenmişse de tarih öğretimi, yurttaşlık ve değer eğitimini destekleyebilecek önemli bir alandır.

2007 yılından itibaren yenilenen sosyal bilgiler dersi kapsamında tarih öğretim programı ve ders kitaplarında daha önce yapılan eleştiriler ve uluslararası gelişmeler ışığında değişiklikler yapılmaya çalışılmıştır. Mevcut program ve ders kitapları incelendiğinde geçmişteki bazı sorunların halen devam ettiği görülmektedir.

\section{Problem Durumu}

Öğretmenlerin öğretim yöntem ve teknikleri, öğrencinin öğretmenin anlattığı her şeyi ezberlemesi gerektiğinin hissettirilmesi, Milli Eğitim ders kitaplarının karmaşık oluşu, görsel olmayışı, kronolojiyi ezberleme korkusu, müfredatın yoğunluğundan dolayı ders dışı etkinliklere zaman ayrılamaması, ünitelerin uzun olması, detaylı bilgilerin veriliyor olması gibi nedenlerden dolayı öğrencide sosyal bilgiler dersine karşı önyargı oluşmuştur (Yanpar, 1997).

Ülkemizde tarih öğretimi alanında yapılan araştırmalar incelendiği zaman, alanda pek çok sorunla karşılaşıldığı görülür. Bu araştırma ve gözlemlere dayalı olarak, bazı eğitim kurumlarında tarih öğretiminin, öğrencilerde ilgi uyandırmadığı, olgulara dayalı, öğretmen merkezli ve gelenekçi bir anlayışla öğretildiği ileri sürülmektedir (Paksoy, 1997; Özbaran, 1998, Tuncay, 1998, Tekeli, 1998a, Tekeli, 1998b, Güler, 2005; Demircioğlu, 2005; 2006). Bu gibi araştırma sonuçlarından anlaşıldığ1 gibi sosyal bilgiler dersinin çeşitli problemleri bulunduğu anlaşılmaktadır.

Yalar (2010) tarafından yapılan araştırmada, ilköğretim sosyal bilgiler programında değerler eğitiminin mevcut durumunun belirlenmesi amaçlanmıştır. Araştırmada elde edilen bazı sonuçlar şu şekildedir: Öğretmenler okulda verilen değerlerin ailede ve sosyal çevrede yeterince pekiştirilmediğini, öğretmenler hizmet öncesi eğitimde değer eğitimi dersi almalarının değerleri öğrencilere kazandırmada yararlı olacağını, iletişim araçlarındaki şiddet ve saldırganlık içeren bazı yayınların okulda verilen 
değerler eğitimini olumsuz etkilediğini belirtmektedirler. Doğanay ve Sarı'nın (2008) yapmış olduğu araştırmada ise sosyal bilgiler programı öğretmen görüşleri doğrultusunda değerlendirmiştir. Elde edilen bulgular sonucunda, öğretmenler sosyal bilgiler öğretim programında en fazla ölçmedeğerlendirme boyutunu olumsuz bulmuşlardır. Ayrıca öğretmenler programın çağdaş eğitim anlayışını yansıttığını düşünmekle birlikte, uygulamada önemli sorunların olduğunu belirtmişlerdir. Programın uygulanmasında gerekli olan toplum, aile, hizmet içi eğitim gereksinimi, araç-gereç ve fiziki koşullar bu sorunların en önemlileri olarak vurgulanmıştır. Bir kısmında ise öğretim programının yeterli olmadı̆̆ı görülmektedir. $\mathrm{Bu}$ bağlamda yapılan çalışmaların bir kısmında sosyal bilgiler dersi tarih öğretiminde değer kazanımının yeterli olmadı̆̆ı, diğer kısmında ise öğretim programının yeterli olmadığı görülmektedir.

$\mathrm{Bu}$ iki sorunun başka boyutlarıyla da incelenmesi, değerlendirilmesi gerekir. Eğitim öğretimin en önemli unsuru olan öğretmenlerin dikkate alınması ve onların görüşlerine başvurulması önemlidir. Bu araştırmada sosyal bilgiler dersi kapsamında öğretmenlerin tarih konularının öğretimine ilişkin görüşlerine başvurulmuştur. Araştırmada öğretim programı kaynaklı unsurlar ile sosyal bilgiler dersi kapsamında tarih öğretiminin toplumsal ihtiyaçları karşılama düzeyi/değer kazanımına ilişkin unsurlar ölçülerek farkındalık oluşturulmaya çalışılmıştır.

Tarih öğretimi değer eğitimi açısından incelendiği zaman, millimanevi, dinî, ahlaki ve sosyal değerlerin oluşturulması ve aktarılmasında alanın değer eğitimine önemli katkılarının olabileceği görülür. Değerlerin geçmişten bugüne neden ve nasıl değiştiği, geçmişteki önemli şahsiyetlerin öğrenciler üzerinde oluşturacağı değerler açısından önemlidir. Bu konu ile ilgili öğretmen görüşleri toplumsal ihtiyaçları karşılama düzeyi ve değer eğitimine katkı sağlayacaktır.

Öğretim programlarının uygulayıcısı olan öğretmenlerin görüşleri ve önerileri oldukça önemlidir. Sosyal bilgiler dersi kapsaminda tarih konularının öğretimi sürecinde öğretim programı hakkında öğretmenlerin görüşlerini tespit etmek ve bu konuya ilişkin öneriler getirmek önemlidir. Ayrıca bu araştırma, Milli Eğitim Bakanlığının sosyal bilgiler dersine yönelik araştırma ve geliştirme hizmetlerine yön vermesi açısından önem arz etmektedir.

Araştırmanın sorusu, "Sosyal bilgiler dersi kapsamında öğretmenlerin tarih konularının öğretimine ilişkin görüşleri nelerdir?" şeklindedir. Araştırmanın alt soruları ise şöyledir: 
1. Sosyal bilgiler dersi kapsamında öğretilen tarih konularının öğrencilerin toplumsal ihtiyaçları karşılama düzeyi/değer kazanımına ilişkin öğretmenlerin görüşleri nelerdir?

2. Sosyal bilgiler dersi kapsamında tarih konularının öğretiminde öğretim programına ilişkin öğretmenlerin görüşleri nelerdir?

$\mathrm{Bu}$ araştırma ortaokullardaki sosyal bilgiler dersi kapsamında öğretilen tarih konularına ilişkin öğretmenlerin görüşleriyle sınırlıdır.

\section{Yöntem}

$\mathrm{Bu}$ araştırmada, sosyal bilgiler öğretmenlerinin özellikle tarih konularının öğretimine ilişkin görüşlerinin belirlenmesi amaçlanmıştır. Bu bağlamda çalışma, nicel ve nitel araştırma yöntemlerinin bir arada kullanıldığı karma yöntem (mixed methods) ile gerçekleştirilmiştir.

Araştırma probleminin bütüncül bir çerçevede ele alınmasına, mantıklı ve sezgisel sonuçlar sunarak problemin en iyi biçimde açıklanmasına olanak sağlayan karma yöntem (Leech ve Onwuegbuzie, 2009; Creswell ve diğerleri, 2003; Morgan, 1998) 1960'lardan günümüze kadar Psikoloji, Sosyoloji, Sağlik Bilimleri, Yönetim ve Organizasyon gibi birçok alanda yapılan bilimsel çalışmalara önemli katkılar sağlamıştır (Onwuegbuzie ve Leech, 2009). Bugün eğitim araştırmalarında da nitel ve nicel yaklaşımların karma yöntem adıyla bütünleştirilerek kullanılması giderek yaygınlaşmakta, bu yöntemin bilimsel çalışmalara yaptığı katkı önemli görülmektedir.

\section{Veri Toplama Aracı}

Sosyal Bilgiler dersi kapsamında öğretmenlerin tarih konularının öğretimine ilişkin görüşlerinin belirlenmesi amacıyla araştırmacı tarafından dört boyuttan oluşan bir ölçek geliştirilmiştir. ${ }^{1}$ Bu makalede sadece toplumsal ihtiyaçları karşılama düzeyi/değer kazanımı ile öğretim programı boyutları ele alınmıştır. Ayrıca bu boyutlarla ilgili öğretmenler arasından seçilen16 kişilik bir grupla da derinlemesine yarı yapılandırılmış mülakat yapılarak araştırma konusuna ilişkin ayrıntılı bilgiler elde edilmiştir.

\section{Nicel Veri Toplama Aracı}

Araştırmanın nicel veri toplama aracı ölçeğin boyutlarına göre değişmektedir.

\footnotetext{
${ }^{1}$ Öğretmen unsuru ile fiziki koşullar ve materyal boyutu başka bir makalede ele alınmıştır.
} 
Bu ölçeğin birinci boyutunda, tarih konularının öğrencilerin değerler eğitimine sağladığı katkılara yönelik öğretmenlerin algısını ölçmeyi amaçlayan sorular yer almaktadır. Toplam 10 adet sorunun yer aldığı bu bölümde ders kapsamında anlatılan konuların öğrencilerin doğal çevre ve tarihi eserleri koruma bilinci, inanç ve ahlak özgürlüğü, hoşgörü ve empati kurma vb. konuları ölçmeyi amaçlayan sorular yer almaktadır (Cronbach Alpha $=0.87$ ).

Ölçeğin ikinci boyutunda tarih konularının öğretiminde öğretim programına ilişkin öğretmenlerin algıları ölçmeyi amaçlayan sorular yer almaktadır. Bu bölümde tarih konularının eğitim programındaki dağılımı, ağırlığı ve yeri, müfredatın değiştirilebilirliği, sınavlar ve ders içeriklerinin uygunluğu vb. konuları içeren 7 adet soru yer almaktadır (Cronbach Alpha $=0.66)$.

Soruların cevaplanması için "tamamen katılıyorum" ve "hiç katılmıyorum" arasında seçeneklerin yer aldığı beşli likert ölçeği kullanılmıştır. Ölçek çalışmasıyla birlikte ortaya çıkan sonuçların daha derinlemesine incelenmesi amacıyla ayrı bir gruptaki 16 öğretmenle yarı yapılandırılmış derinlemesine mülakat yapılmıştır. Ölçek soruları hazırlanırken öncelikle literatürde daha önce konuyla ilgili yapılan araştırmalar taranmıştır. Yapılan bu çalışmalar sonucunda 100 soruluk ölçek hazırlanmıştır. Bu sorular 3 uzmana 4 defa inceletilerek gerekli düzeltmeler yapılmıştır. Bu düzeltmeler sonucunda ölçek 88 soruya indirilmiştir. Bu sorular üzerinde bir uzman eşliğinde kategorik gruplama yapılarak bazı sorular çıkarılmıştır. Böylece soru sayısı 55'e düşürülmüştür. Yapılan pilot çalışma sonucunda soruların bazılarının tekrar olduğu, bazılarının anlaşılmadığı, konu başlığına uygun olmadığı sonucuna varılmıştır. Problemli görülen bu tür sorular ölçek formundan çıkartılmıştır. Sorular üzerinde gerekli düzenleme yapılarak soru sayısı 17'ye düşürülmüştür.

\section{Nitel Veri Toplama Aracı}

Nitel veriler için araştırmacı tarafından öncelikli olarak 16 soru belirlenmiştir. Daha sonra nicel çalışma sonrası ortaya çıkan faktör analizi sonucunda ortaya çıkan boyutlar doğrultusunda sorular 1 adet öğretmen kişisel bilgileri, 1 adet görüş ve öneriler, 6 adette boyutları destekleyecek nitelikte toplam 8 soruluk form haline getirilmiştir. Ayrıca hazırlanan sonda sorularla mülakat sırasında öğretmenlerden detaylı bilgiler alınmaya çalışılmıştır.

Öğretmenlerle gönüllülük esasına dayalı görüşme yapılmıştır. Görüşme öncesi kısa bilgilendirme yapıldıktan sonra görüşmeye geçilmiştir. 
Daha önce hazırlanan sorular kendilerine yöneltilerek mülakat yapılmıştır. Görüşmeler genellikle öğretmenler odasında, idarenin ve öğretmenlerin uygun bulduğu zaman aralığında gerçekleşmiştir. Ortalama görüşme süresi 30-45 dakika arasında gerçekleşmiş̧ir. Görüşmeler toplamda 3 haftada tamamlanmıştır.

\section{Verilerin Çözümlemesi}

Nicel verilerin analizinde bağımsız $t$ testi ve tek yönlü varyans analizleri (ANOVA) ve farklılığa neden olan grubun tespitinde Tukey PostHoc testi gibi istatistiksel yöntemler kullanılmıştır. Ayrıca araştırmada veriler değerlendirilirken tamamlayıcı istatistiksel metotlar (Sayı, Yüzde, Ortalama, Standart sapma) kullanılmıştır.

Nitel verilerde ise önce elde edilen veriler deşifre edilerek metin haline dönüştürülmüştür. Deşifre edilen metinler, sorulara göre sınıflandırılmıştır. Öğretmenlerin verdikleri yanıtlardan birbirine anlam olarak yakın olanlar gruplandırılmıştır. Yapılan gruplamalar tablolara aktarılmıştır. Çıkan sonuçlar araştırmanın bulgular kısmında yorumlanmıştır.

\section{Evren ve Örneklem}

Araştırmanın evreni, 2014-2015 eğitim öğretim yılında İzmir ilinde 502 devlet ortaokulunda görev yapan 1132 sosyal bilgiler öğretmenidir. Örneklemi ise İzmir ili merkez ilçeleri arasından basit tesadüfi örneklem tekniği (simple random) ile 4 ilçe seçilmiştir. Yapılan örneklem seçiminde Bayraklı, Karşıyaka, Karabağlar ve Konak ilçeleri seçilmiştir. İkinci aşamada seçilen bu ilçelerde yer alan ortaokullar arasında yine basit rastgele örneklem tekniği kullanılarak en az 80 okul seçilmiştir, üçüncü aşamada ise seçilen bu 80 okulda görev yapan 303 sosyal bilgiler öğretmenine hazırlanan anket formları dağıtılmıştır. \%95'lik güvenirlik seviyesi göz önüne alındığında tesadüfi yöntemle seçilen 303 öğretmen evreni yansıtacağ değerlendirilmektedir (Yazıcıoğlu ve Erdoğan, 2004). Bu öğretmenlerin 149 (\% 49,2)'u kadın, 154 (\% 50,8)'ü erkektir. 


\section{Bulgular}

Bulgular kısmında iki boyut üzerinde durulmuştur. Toplumsal ihtiyaçları karşılama düzeyi / değer kazanımıyla ilgili öğretmen görüşleri birinci boyut; sosyal bilgiler dersi öğretim programıla ilgili öğretmen görüşleri ise ikinci boyutu oluşturmaktadır.

Birinci Boyut: Toplumsal İhtiyaçları Karşılama Düzeyi / Değer Kazanımı Bulguları

Araştırmada öncelikle nicel araştırma bulguları üzerinde durulmuştur. Tablo 1'de çalışmaya katılan öğretmenlerin mezun oldukları bölümleri gösterilmektedir:

Tablo 1. Sosyal Bilgiler dersi öğretmenlerin mezun oldukları bölümlere göre dağılımı

\begin{tabular}{lll}
\hline Mezun Olunan Bölüm & Sayı & Yüzde \\
\hline Sosyal Bilgiler Öğretmenliği & 129 & $\% 42,6$ \\
Tarih Öğretmenliği & 65 & $\% 21,4$ \\
Tarih (Fen Edebiyat) Bölümü & 50 & $\% 16,5$ \\
Coğrafya Öğretmenliği & 44 & $\% 14,5$ \\
Diğer & 15 & $\% 5,0$ \\
\hline Toplam & $\mathbf{3 0 3}$ & $\mathbf{\% 1 0 0}$ \\
\hline
\end{tabular}

Tablo 1'e göre, öğretmenlerin $129^{\prime} \mathrm{u}$ sosyal bilgiler öğretmenliği, 65'i tarih öğretmenliği, 50'si tarih bölümü (fen edebiyat), 44'ü coğrafya öğretmenliği, 10'u coğrafya bölümü (fen edebiyat) ve son olarak da 15'i diğer bölümlerden mezun olduğu görülmektedir. Çalışmaya katılan öğretmenlerin mezun oldukları bölümler incelendiğinde en fazla sosyal bilgiler öğretmenliği mezunu öğretmenlerin olduğu anlaşılmaktadır.

Toplumsal ihtiyaçları karşılama düzeyi / değer kazanımına ilişkin öğretmen algılarının mezun oldukları bölümlere göre farklılık gösterip göstermediğini ölçmek amacıyla yapılan ANOVA analiz sonuçları Tablo 2'de gösterilmiştir: 
Tablo 2. Toplumsal ihtiyaçları karşılama düzeyi / değer kazanımına ilişkin öğretmen algıları ile onların mezun oldukları bölümlere göre karşılaştırılması

\begin{tabular}{clccccc}
\hline Boyutlar & $\begin{array}{c}\text { Varyans } \\
\text { Kaynakları }\end{array}$ & $\begin{array}{c}\text { Kareler } \\
\text { Toplamı }\end{array}$ & $\begin{array}{c}\text { Serbestlik } \\
\text { Derecesi }\end{array}$ & $\begin{array}{c}\text { Kareler } \\
\text { Ortalaması }\end{array}$ & F & $\mathbf{p}$ \\
\hline \multirow{2}{*}{ Değer } & $\begin{array}{l}\text { Gruplar } \\
\text { Kazanımı }\end{array}$ & 61,499 & 4 & 15,375 & \multirow{2}{*}{, 873} &, 828 \\
& $\begin{array}{l}\text { Grup içi } \\
\text { Toplam }\end{array}$ & 12281,716 & 298 & 41,214 & & \\
& 12343,215 & 302 & & & \\
\hline
\end{tabular}

Tablo 2'de, öğretmenlerin mezun oldukları bölüme göre ders kapsamında öğretilen konuların öğrencilerin toplumsal ihtiyaçlarını karşılama düzeyine ilişkin öğretmen algılarında anlamlı bir farklılık olmadığ 1 belirlenmiştir $\left(\mathrm{F}_{4-298}=, 373 ; \mathrm{p}>.05\right)$. Buna göre, farklı bölümlerden mezun olan öğretmenlerin toplumsal ihtiyaçları karşılama düzeyi / değer kazanımına ilişkin algılarının aynı olduğu söylenebilir.

Tablo 3'te öğretmenlerin tarih öğretimine ilişkin algılarının öğretmenin hizmet içi kursa katılıp katılmamasına göre karşılaştırılması gösterilmiştir:

Tablo 3. Öğretmenlerin tarih öğretimine ilişkin değer kazanımı algılarının öğretmenin hizmet içi kursa katılıp katılmamasına göre karşılaştırılması

\begin{tabular}{llcccccc}
\hline \multirow{2}{*}{ Boyutlar } & \multicolumn{2}{c}{ Hizmeti İçi } & & & & & \\
& Eğitim Kursu & $\mathbf{N}$ & $\overline{\boldsymbol{X}}$ & Ss. & Sd. & $\mathbf{t}$ & $\mathbf{p}$ \\
\hline Değer & Katılan & 63 & 39,4921 & 6,07712 & 301 & 2,598 & $0,010^{* *}$ \\
Kazanımı & & & & & & \\
& Katılmayan & 240 & 37,1625 & 6,39778 & & & \\
\hline
\end{tabular}

Tablo 3'te hizmet içi eğitim kurslarına katılan öğretmenler ile katılmayan öğretmenlerin verdikleri cevapların bağımsız $\mathrm{t}$ testi sonuçlarını yansıtılmaktadır. Toplumsal ihtiyaçları karşılama düzeyine ilişkin sorulara verilen cevaplarda hizmet içi eğitimlere katılan öğretmenlerin ortalaması $(X=39,49)$, hizmet içi eğitim kurslarına katılmayan öğretmenlere göre $(X=37,16)$ daha yüksektir. Katılanlar yönünde anlamlı bir farklılık olduğu belirlenmiştir ( $\left.\mathrm{t}_{301}=2,598 ; \mathrm{p}<.01\right)$. Bu fark hizmet içi eğitime katılanlar yönünde algıların olumlu yönde daha yüksek olduğu söylenebilir.

Toplumsal ihtiyaçları karşılama düzeyi / değer kazanımına ilişkin öğretmenlerin algılarının öğretmenlerin çalıştıkları meslek yılına göre değişiklik gösterip göstermediğini test etmek amaciyla tek yönlü ANOVA 
testi kullanılmıştır. Toplumsal ihtiyacı karşılama düzeyi / değer kazanımına ilişkin ANOVA testi Tablo 4'te gösterilmiştir:

Tablo 4. Öğretmenlerin değer kazanımı algıları ile mesleki tecrübe ANOVA test sonuçları

\begin{tabular}{clccccc}
\hline Boyutlar & $\begin{array}{c}\text { Varyans } \\
\text { Kaynakları }\end{array}$ & $\begin{array}{c}\text { Kareler } \\
\text { Toplamı } \\
\text { (SS) }\end{array}$ & $\begin{array}{c}\text { Serbestli } \\
\mathbf{k} \\
\text { Derecesi } \\
\text { (df) }\end{array}$ & $\begin{array}{c}\text { Kareler } \\
\text { Ortalama } \\
\text { s1 (MS) }\end{array}$ & $\mathbf{F}$ & $\mathbf{p}$ \\
\hline Değer & Gruplar & 600,478 & 4 & 150,119 & 3,810 &, $005^{* *}$ \\
Kazanımı & arası & & & & & \\
& Grup içi & 11742,737 & 298 & 39,405 & & \\
& Toplam & 12343,215 & 302 & & & \\
\hline
\end{tabular}

${ }^{* *} \mathrm{p} \leq 0,01$

Tablo 4'te, test sonuçları incelendiğinde meslek tecrübesi (çalışma yılı) ile öğretmenlerin derste anlatılan konuların öğrencilerin toplumsal ihtiyaçlarını karşılama düzeyine ilişkin algıları arasında anlamlı bir farklılık olduğu belirlenmiştir $\left(\mathrm{F}_{4-298}=3,810 ; \mathrm{p}<.05\right)$. Farklılığın kaynağını belirlemek için Tukey HSD testi yapılmış ve Tablo 5'te gösterilmiştir:

Tablo 5. Toplumsal ihtiyaçlarını karşılama düzeyine ilişkin öğretmen algıları ile mesleki tecrübesine ait Tukey HSD testi

\begin{tabular}{lllll}
\hline Grup & $\begin{array}{l}\text { Mesleki Tecrübe } \\
\text { (Çalışma Y1lı) }\end{array}$ & $\mathbf{N}$ & Ortalamalar & $\begin{array}{l}\text { Gruplar } \\
\text { Aras1 Fark }\end{array}$ \\
\hline 1 & $1-5$ y1l & 47 & 37,2553 & \\
2 & $6-10$ y1l & 51 & 36,7255 & $5-2$ \\
3 & $11-15$ yıl & 67 & 37,3433 & \\
4 & $16-20$ y1l & 71 & 36,4366 & $5-4$ \\
5 & 21 ve üzeri & 67 & 40,2090 & \\
\hline
\end{tabular}

Tablo 5 incelendiğinde, mesleki tecrübe arttıkça öğretmenlerin derste anlatılan konuların öğrencilerin toplumsal ihtiyaçlarını karşılama düzeyine ilişkin algıları artmaktadır. Bu soruya verilen cevaplar arasında ortalaması en yüksek olan grup meslek tecrübesi en fazla olan beşinci grup (21 yıl ve daha üzeri) olmuştur.

Birinci boyutun nicel bulgulardan sonra nitel bulgularına yer verilmiştir. Tablo $6^{\prime} \mathrm{da}$ sosyal bilgiler öğretmenlerinin öğrenciye kazandırmayı düşündükleri değerlere ilişkin görüşlere yönelik örnek 
ifadeleri gösterilmiştir:

Tablo 6. Sosyal Bilgiler öğretmenlerinin öğrenciye kazandırmayı düşündükleri değerlere ilişkin görüşlere yönelik örnek ifadeleri

\begin{tabular}{|c|c|}
\hline $\begin{array}{l}\text { Öğret. } \\
\text { sayısı }\end{array}$ & Örnek ifadeleri \\
\hline 13 & $\begin{array}{l}\text { Yardımlaşma, hoşgörü, evrensel değerler, insan hakları, saygı } \\
\text { sevgi, eşitlik, özgürlük ve ahlaki değerler gibi değerleri } \\
\text { vermeye çalışıyorum. }\end{array}$ \\
\hline 7 & $\begin{array}{l}\text { Günümüz ve geleceği daha iyi yorumlama becerisi } \\
\text { kazandırıyorum. }\end{array}$ \\
\hline 6 & $\begin{array}{l}\text { Sorumluluk bilincine sahip, vatan ve milletine bağlı gençler } \\
\text { yetiştiriyorum. }\end{array}$ \\
\hline 5 & $\begin{array}{l}\text { Geçmişten dersler çıkararak aynı hatalara düşmemeleri } \\
\text { gerektiğini anlatıyorum. }\end{array}$ \\
\hline 3 & Öğrencilere tarih bilinci kazandırıyorum. \\
\hline 3 & $\begin{array}{l}\text { Tarihte önemli işler yapmış kişileri anlatarak öğrencilerin } \\
\text { onları örnek almaları gerektiğini anlatıyorum. }\end{array}$ \\
\hline 2 & Örnek davranışlarla onlara rol model olmaya çalışıyorum. \\
\hline
\end{tabular}

Tablo 6'da öğretmenlerin öğrenciye kazandırmayı düşündükleri değerlere ilişkin görüşlere yer verilmiştir. Görüşülen 13 öğretmen yardımlaşma, hoşgörü, evrensel değerler, insan hakları, saygı sevgi, eşitlik, özgürlük ve ahlaki değerler gibi değerleri vermeye çalıştıklarını ifade etmişlerdir. 7 öğretmen ise günümüz ve geleceği daha iyi yorumlama becerisi kazandırmaya çalıştıklarını söylemiştir. 6 öğretmen ise sorumluluk bilincine sahip, vatan ve milletine bağlı gençler yetiştirdiklerini savunmuşlardır. 5 öğretmen ise geçmişten dersler çıkararak aynı hatalara düşmemeleri gerektiğini anlattıklarını belirtmişlerdir. 3 öğretmen öğrencilere tarih bilinci kazandırdıklarını söylemiştir. 3 öğretmen tarihte önemli işler yapmış kişileri anlatarak öğrencilerin onları örnek almaları gerektiğini anlattıklarını belirtmiştir. 2 öğretmen ise örnek davranışlarla onlara rol model olmaya çalıştıklarını vurgulamışlardır. Bunun dışında birer öğretmen de sosyal bilgilerin yaşamla iç içe bir ders olduğunu gösterdiğini; atalarımızın mirasına sahip çıkarak Atatürk ilke ve inkılapları doğrultusunda öğrencileri yetiştirmeye çalıştı̆̆ını; sorgulama, düşünme, analitik düşünce becerisini kazandırmaya çalıştığını ifade etmiştir.

Araştırmadan elde edilen öğretmen görüşlerine göre, öğrenciye kazandırılacak en önemli değerler; milli bilince sahip, sorumluluk bilinci gelişmiş, ahlaki değerleri benimseyen, dayanışma, hoşgörü, saygı, sevgi, 
eşitlik, özgürlüktür. Ayrıca hedeflenen önemli değerlerden biri de öğrenciye analitik düşünce becerisi kazandırmaktır.

İkinci Boyut: Sosyal Bilgiler Dersi Öğretim Programından Kaynaklanan Öğretmen Algıları İle İlgili Bulgular

İkinci boyutta da öncelikle nicel araştırma bulguları üzerinde durulmuştur. Tablo 7'de öğretim programından kaynaklanan unsurların öğretmenlerin algıları ile onların mezun oldukları bölümlere göre karşılaştırılması verilmiştir:

Tablo 7. Öğretim programından kaynaklanan unsurların öğretmen algıları ile onların mezun oldukları bölümlere göre karşılaştırılması

\begin{tabular}{llllccc}
\hline Boyutlar & $\begin{array}{l}\text { Varyans } \\
\text { Kaynakları }\end{array}$ & $\begin{array}{l}\text { Kareler } \\
\text { Toplamı }\end{array}$ & $\begin{array}{l}\text { Serbestlik } \\
\text { Derecesi }\end{array}$ & $\begin{array}{c}\text { Kareler } \\
\text { Ortalama } \\
\text { si }\end{array}$ & F & p \\
\hline $\begin{array}{l}\text { Öğretim } \\
\text { Programın }\end{array}$ & $\begin{array}{l}\text { Gruplar } \\
\text { arası }\end{array}$ & 161,718 & 4 & 40,429 & & \\
$\begin{array}{l}\text { dan Kay. } \\
\text { Unsurlar }\end{array}$ & $\begin{array}{l}\text { Grup içi } \\
\text { Toplam }\end{array}$ & 5956,401 & 298 & & 2,431 & .048 \\
& & 5118,119 & 302 & 16,632 & & \\
\hline
\end{tabular}

Tablo 7'de, öğretmenlerin mezun oldukları bölüme göre öğretim programından kaynaklanan unsurların öğretmen algılarında anlamlı bir farklılık olduğu belirlenmiştir $\left(\mathrm{F}_{4-298}=2,431 \mathrm{p}<.05\right)$.

Sosyal Bilgiler Dersi Öğretim Programına ilişkin öğretmen algılarının onların mezun oldukları bölümlere göre farklılık gösterip göstermediğini ölçmek amacıyla yapılan Tukey HSD testi sonuçları Tablo 8'de gösterilmiştir: 
Tablo 8. Öğretim programına ilişkin öğretmen algıları ile onların mezun oldukları bölümlere karşılaştırılması

\begin{tabular}{clccc}
\hline Grup & Mezun Olunan Bölüm & N & Ortalamalar & $\begin{array}{c}\text { Gruplar Arası } \\
\text { Fark }\end{array}$ \\
\hline 1 & Sosyal Bilgiler & 129 & 26,7054 & $5-1$ \\
& Öğretmenliği & & & \\
2 & Tarih Öğretmenliği & 65 & 25,9077 & \\
3 & Coğrafya Öğretmenliği & 44 & 26,5682 & \\
4 & Tarih Bölümü (Fen & 50 & 25,7400 & \\
& Edebiyat) & & & \\
5 & Diğer Bölümler & 15 & 23,5333 & \\
\hline
\end{tabular}

Tablo 8'de, öğretmenlerin mezun oldukları bölümlere göre yapılan karşılaştırmada, sosyal bilgiler dersi kapsamında tarih konularının öğretimine ilişkin öğretim programından kaynaklanan unsurlara dair algılarda ortalaması en yüksek olan grup birinci grup (sosyal bilgiler öğretmenleri) olmuştur. Bu durum sosyal bilgiler öğretmenliği bölümü mezunu olan öğretmenlerin diğer branşlarla karşılaştırıldığında derse ilişkin öğretim programını daha çok yetersiz bulduklarını ortaya koymaktadır.

Tablo 9'da öğretmenlerin öğretim programına ilişkin algılarının öğretmenlerin hizmet içi kursa katılıp katılmamasına göre karşılaştırılması gösterilmiştir:

Tablo 9. Öğretim programına ilişkin algılarının öğretmenin hizmet içi kursa katılıp katılmamasına göre karşılaştırılması

\begin{tabular}{|c|c|c|c|c|c|c|c|}
\hline Boyutlar & $\begin{array}{l}\text { Hizmeti İçi Eğitim } \\
\text { Kursuna Katıldınız } \\
\text { mı? }\end{array}$ & $\mathbf{N}$ & $\overline{\boldsymbol{X}}$ & Ss. & Sd. & $\mathrm{T}$ & p \\
\hline ğrt. & Katılan & 63 & 26,7619 & 4,07080 & 301 & 1,223 & 0,222 \\
\hline $\begin{array}{l}\text { Programindan } \\
\text { Kay. Unsurlar }\end{array}$ & Katılmayan & 240 & 26,0500 & 4,12432 & & & \\
\hline
\end{tabular}

Tablo 9'da öğretim programına ilişkin alg1 boyutunda gruplar arasında anlamlı bir farklılığın olmadığ Dolayısıyla bu boyut için grupların benzer cevaplar verdikleri sonucuna ulaşılmıştır. Buna göre, öğretmenlerin öğretim programından kaynaklanan algılarını etkilememiş̧ir.

Tablo $10^{\prime}$ da öğretim programından kaynaklanan unsurlar ve mesleki tecrübe ile ilgili Tukey HSD testi sonuçlarına yer verilmiştir: 
Tablo 10. Öğretim programından kaynaklanan unsurlar ile mesleki tecrübenin karşılaștırılması

\begin{tabular}{llccccc}
\hline Boyutlar & $\begin{array}{l}\text { Varyans } \\
\text { Kaynakları }\end{array}$ & $\begin{array}{l}\text { Kareler } \\
\text { Toplamı }\end{array}$ & $\begin{array}{l}\text { Serbestli } \\
\mathbf{k} \\
\text { Derecesi }\end{array}$ & $\begin{array}{l}\text { Kareler } \\
\text { Ortalaması }\end{array}$ & F & p \\
\hline $\begin{array}{l}\text { Öğretim } \\
\begin{array}{l}\text { Programından. } \\
\text { Kaynaklanan } \\
\text { Unsurlar }\end{array}\end{array}$ & $\begin{array}{l}\text { Gruplar } \\
\text { arası }\end{array}$ & 142,314 & 4 & 35,578 & 2,131 &, 077 \\
\hline $\begin{array}{l}\text { Grup içi } \\
\text { Toplam }\end{array}$ & 4975,805 & 298 & 16,697 & & \\
\hline
\end{tabular}

Tablo 10'a göre, öğretim programından kaynaklanan unsurların öğretmenler tarafından algıları ile mesleki tecrübeleri arasında anlamlı bir farklılık olmadığı belirlenmiştir $\left(\mathrm{F}_{4-298}=2,131 ; \mathrm{p}>.05\right)$. Buna göre mesleki tecrübenin az veya çok olması öğretim programı hakkındaki algıyı değiştirmediği söylenebilir.

İkinci boyutun nicel bulgulardan sonra nitel bulgularına yer verilmiştir. Tablo $11^{\prime}$ de Sosyal Bilgiler öğretmenlerinin öğretim programından kaynaklanan sorunlara ilişkin görüşlere yönelik örnek ifadeleri gösterilmiştir:

Tablo 11. Sosyal Bilgiler öğretmenlerinin öğretim programından kaynaklanan sorunlara ilişkin örnek ifadeleri

\begin{tabular}{|c|c|}
\hline $\begin{array}{l}\text { Öğret. } \\
\text { Sayısı }\end{array}$ & Örnek ifadeleri \\
\hline 10 & $\begin{array}{l}\text { 7. sınıflarda konu bütünlü̆̆̈̈ yok ve konular çocukların } \\
\text { seviyesine uygun değildir. }\end{array}$ \\
\hline 7 & Müfredat yoğun buna karşın ders saati yetersizdir. \\
\hline 5 & Ders kitapları yetersizdir. \\
\hline 4 & $\begin{array}{l}\text { 5. sinuflarda Atatürk ilkeleri konusu çocukların seviyesine } \\
\text { uygun değildir. }\end{array}$ \\
\hline 4 & $\begin{array}{l}\text { 8. sinıflarda mevcut ders saati ile inkılap tarihi konuları } \\
\text { yetişmediği için hızlı geçilmektedir. }\end{array}$ \\
\hline 4 & $\begin{array}{l}\text { Ders kitapları ve öğrenci çalışma kitaplarındaki etkinlikler } \\
\text { çocukların seviyesinin üstündedir. }\end{array}$ \\
\hline 2 & Öğretmen zümreleri verimli değildir. \\
\hline
\end{tabular}

Tablo 11'de öğretim programından kaynaklanan sorunlara ilişkin öğretmen görüşlerine yer verilmiştir. Bu kategoride 10 öğretmen 7 . sınıflarda konu bütünlüğünün olmadığını, konuların çocukların seviyesine 
uygun olmadığını, "Osmanlı tarihi içindeki konu akışı ders işlenişini etkiliyor, konular padişah, padişah verilmeliydi" şeklinde ifade etmişlerdir. 7 öğretmen müfredatın yoğun olmasına karşın ders saatinin yetersiz olduğunu söylemiştir. 5 öğretmen ders kitaplarının yetersizliğinden bahsederek, görsellerle zenginleştirilip harita ve resim konulması gerektiğini belirtmiştir. 4 öğretmen 5. sinıflarda Atatürk ilkeleri konusunun çocukların seviyesine uygun değil diyerek 8 . sınıfta verilmesi gerektiğini savunmuştur. 4 öğretmen 8. sinıflarda mevcut ders saati ile inkılap tarihi konuları yetişmediği için hızlı geçildiğini söyleyerek bu durumla ilgili çözüm olarak öğretmenlerden bir tanesi vatandaşlık dersinde de inkılap tarihi konuları işlediğini, çoğu öğretmeninde bu şekilde yaptığını belirtmiştir. 4 öğretmen ders kitaplarında ve çalışma kitaplarındaki etkinliklerin çocukların seviyesinin üstünde olduğunu savunmuştur. 2 öğretmen zümrelerin verimli olmadığını söylemiştir. Bunun dışında birer öğretmen de merkezi sınavlarda sosyal bilgiler dersi sorularının katsayısının düşük olması öğrenci ve veli motivasyonunu etkilediğini; derslerin milli tarih ve milli coğrafya şeklinde ayrılması gerektiğini belirtmiştir.

Araştırmadan elde edilen sonuçlara göre öğretmenler, konular arasında bütünlük olmadığı gibi bazı konuların öğrencilerin seviyelerinin üzerinde olduğunu ifade etmiştir. Ayrıca öğretim programının yoğun olmasına karşın ders saatlerinin yetersiz olduğunu, programın güncellenerek kapsamının daraltılması gerektiğini belirtmişlerdir. Bu durum ise, öğretim programında sorunlar olduğunu ortaya koymaktadır.

\section{Tartışma, Sonuç ve Öneriler}

Araştırmada Sosyal Bilgiler dersi öğretmenlerinin toplumsal ihtiyaçları karşılama düzeyi / değer kazanımı algıları ile Sosyal Bilgiler Dersi Öğretim Programına ilişkin görüşleri üzerinde durulmuştur. Araştırmanın sonuçları boyutlara göre ele alınmıştır.

\section{Sonuçları \\ Toplumsal İhtiyaçları Karşılama Düzeyi / Değer Kazanımı}

Araştırmada, öğretmenlerin mezun oldukları bölümler ile tarih konularının öğretimine ilişkin öğrencilerin toplumsal ihtiyaçlarını karşılama düzeyine / değer kazanımına ilişkin öğretmen algılarında anlamlı bir farklılık olmadığ bölümlerden mezun olan öğretmenlerin toplumsal ihtiyaçları karşılama düzeyi / değer kazanımına ilişkin algılarının aynı olduğu söylenebilir. Uçar (2009)'ın yaptığı araştırmada ise sosyal bilgiler programındaki değerlerle ilgili kazanımlara yönelik ilköğretim okullarında görev yapan sosyal bilgiler 
4 ve 5 . sınıf öğretmenlerinin görüşleri incelenmiştir. Bu araştırmada da branş değişkenleri açısından anlamlı bir farklılık olmadığı belirlenmiştir.

Toplumsal ihtiyaçları karşılama düzeyine / değer kazanımına ilişkin sorulara verilen cevaplarda hizmet içi eğitimlere katılan öğretmenlerin ortalaması ( $X=39,49)$, hizmet içi eğitim kurslarına katılmayan öğretmenlere göre $(X=37,16)$ daha yüksektir. Katılanlar yönünde anlamlı bir farklılık olduğu belirlenmiştir ( $\left.\mathrm{t}_{301}=2,598 ; \mathrm{p}<.01\right)$. Bu fark hizmet içi eğitime katılanlar yönünde algıların olumlu yönde daha yüksek olduğunu ortaya koyuyor. Bu konu ile ilgili yapılan diğer araştırmalarda öğretmenlerin değer eğitimini nasıl gerçekleştireceğine yönelik hizmet içi eğitim etkinlikleri düzenlenmesi gerektiği belirtilmiştir. Ayrıca tarih öğretmenlerinin büyük çoğunluğunun değer eğitimi konusunda örgün eğitim kurumlarında herhangi bir eğitim almadıkları anlaşılmaktadır. Araştırmaya katılan öğretmenler, gerek üniversite öğreniminde gerekse görev süresince hizmet içi eğitim çalışmalarında değer eğitimi konusunda eğitim verilmesi gerektiğini düşünmektedirler (Tokdemir, 2007; Deveci-Ay, 2009).

Araştırmada mesleki tecrübe (çalışma yılı) değişkenine göre öğretmenlerin algı düzeylerinin "derste anlatılan konuların öğrencilerin toplumsal ihtiyaçlarını karşılama düzeyine ilişkin" alt boyutunda gruplar arasında anlamlı bir farklılık olduğu görülmüştür $(F=3,810, p \leq 0,01)$. Buna göre çalışma yılı en fazla olan (21 yıl ve üzeri) grubun ortalamalarının diğer gruplara göre yüksek olduğu gözlenmiştir $(X=40,21)$. Diğer bir ifadeyle mesleki tecrübesi yüksek olan sosyal bilgiler dersi kapsamında öğretilen tarih konularının diğer öğretmenlerle karşılaștırıldığında değer kazanımına daha fazla değer verdiği gözlenmiștir. Öğretmenler sosyal bilgiler dersi kapsamında öğretilen tarih konularının diğer öğretmenlerle karşılaştırıldığında değer kazanımına daha fazla değer verdiği gözlenmiştir. Benzer şekilde yapılan çalışmada, Öğretmenlerin mesleki kıdemleri açısından etkili değer eğitimi, programda değer ve tüm alt boyutların genel toplamına ilişkin görüşleri arasında anlamlı bir farklılığa rastlanmazken; aile-çevre-medya alt boyutuna ilişkin görüşleri arasında $\mathrm{p}<.05$ önem düzeyinde anlamlı bir farklılık olduğu bulunmuştur. Aile-çevre-medya alt boyutuna ilişkin öğretmen görüşleri, 26 yıl ve üzeri mesleki kıdeme sahip beşinci sınıf öğretmenlerinin değer eğitimine ilişkin görüşlerinin, diğer öğretmenlere göre daha olumlu olduğu sonucuna varılmıştır. Bu bulgular ışığında, değerlerin öğretiminde, 26 yıl ve üzeri mesleki kıdeme sahip öğretmenlerin değerlerin öğretiminde yeni bilgilerle mezun olmuş öğretmenlere göre, daha olumlu görüşlere sahip olmaları, değer öğretimine daha duyarlı olmalarının sonucu şeklinde açıklanabilir (Başçı, 2012). 
"Sosyal bilgiler dersi ile öğrencilere hangi değerleri kazandırmayı düşünüyorsunuz?" sorusuna yönelik olarak öğretmenler öğrencilere verilecek değerlerle ilgili şu görüşlerde bulunmuşlardır: Evrensel ve ahlaki değerler, sorumluluk bilinci, vatan ve milletine bağlllık, günümüz ve geleceği daha iyi yorumlama becerisi ve tarih bilinci, davranışlarla onlara rol model olma, Atatürk ilke ve inkılapları doğrultusunda öğrencileri yetiştirme, sorgulama, düşünme, analitik düşünce becerileridir. Bu durum sosyal bilgiler dersinde öğrencilere değer eğitimi verildiğini göstermektedir. Benzer şekilde yapılan çalışmalarda, sosyal bilgiler dersi aracılığı ile öğrencilere bireysel, kültürel ya da evrensel içerikli değerler kazandırılabilir. $\mathrm{Bu}$ değerler; iyi vatandaş yetiştirilmesi, insana hoşgörü kazandırması, zihinsel becerileri geliştirmesi, vatan, millet, bayrak, devlet, yönetme biçimini, hak ve sorumluluklarını bilmesidir (NCSS, 1993; Haaberli, 2005; Yiğittir-Öcal, 2011).

\section{İkinci Boyut: Sosyal Bilgiler Dersi Öğretim Programından Kaynaklanan Öğretmen Algıları İle İlgili Sonuçlar}

Öğretmenlerin "öğretim programına ilişkin unsurlar konusunda öğretmenlerin algılarına ilişkin değerlendirmeleri" mezun oldukları bölümlere göre değişiklik gösterip göstermediği konusundaki analiz sonuçlarına göre ise gruplar arasında alt boyutunda anlamlı bir farklılık olduğu gözlenmiştir ( $\mathrm{F}=2,431, \mathrm{p} \leq 0,05)$. Bu boyutla ilgili ortalaması en yüksek olan grubun sosyal bilgiler öğretmenleri olduğu görülmüştür $(X=26,71)$. Bu durum sosyal bilgiler öğretmenliği bölümü mezunu olan öğretmenlerin diğer branşlarla karşılaştırıldığında derse ilişkin öğretim programını daha çok yetersiz bulduklarını ortaya koymaktadır. Benzer şekilde yapılan çalışmada, sosyal bilgiler dersinin vatandaşlık aktarımı sağlamasına ilişkin maddelere öğretmenlerin verdikleri cevaplara göre fen edebiyat ile eğitim fakültesi mezunu öğretmenler arasında anlamlı bir farklılık olduğu belirlenmiştir $(p<, 05)$. Fen edebiyat fakültesi mezunu olan öğretmenler bu gruptaki sorulara daha olumlu cevaplar vermişlerdir. Gruptaki eğitim fakültesi mezunu öğretmenlerinin önemli bir kısmının, daha önceki sosyal bilgiler müfredatıyla öğretim yapmamış ya da kısa süre yapmış olmaları buna karşın fen edebiyat fakültesi mezunu öğretmenlerin eski müfredatı uzun süre kullanmış olmaları böyle bir farklılığa neden olmuş olabilir. 1998200 yılları arasında kullanılan eski sosyal bilgiler müfredatında vatandaşlık aktarımı sadece bilgilerin aktarılması olarak düşünüldüğünden fen edebiyat fakültesi mezunu öğretmenler güncel müfredatı daha olumlu bulmaktadır (Polat, 2012). 
Araştırmada, öğretim programına ilişkin algı boyutunda gruplar arasında anlamlı bir farklılığın olmadığ 1 belirlenmiştir ( $\mathrm{t}_{301}=1,223 ; \mathrm{p}>.05$ ). Dolayısıyla bu boyut için grupların benzer cevaplar verdikleri sonucuna ulaşılmıştır. Buna göre, öğretmenlerin öğretim programından kaynaklanan algılarını etkilememiştir. Araştırmada öğretim programından kaynaklanan unsurların öğretmenler tarafından algıları ile mesleki tecrübeleri arasında anlamlı bir farklılığın olmadığ 1 belirlenmiştir $\left(\mathrm{F}_{4-298}=2,131 ; \mathrm{p}>.05\right)$. Buna göre mesleki kıdemin az veya çok olması öğretim programı hakkındaki algıyı değiştirmediği söylenebilir. Bu konu ile ilgili yapılan araştırmalarda katılımcıların meslekî kıdemleri, hizmet içi eğitim seminerlerine katılma durumları, görev yapılan yerleşim yerinin sosyoekonomik özelliği ve öğretmen görüşleri arasında anlamlı bir farklılığın olmadığı belirlenmiştir (Bulut, 2006; Hürsen- Uzunboylu, 2008).

Araştırmada, "Sosyal bilgiler dersi öğretim programının en büyük eksiklikleri nelerdir?" sorusuna öğretmenler öğretim programının yoğun olmasına karşın ders saatlerinin yetersiz olduğunu, programın güncellenerek kapsamının daraltılması gerektiğini belirtmişlerdir. Bu durum öğretim programında sorunlar olduğunu ortaya koymaktadır. Bu konu ile ilgili yapılan araştırmalarda sosyal bilgiler öğretmenlerinin, ders öğretimi planlama aşamasında işlenecek ünite ve konuların fazla olmasına karşın verilen zamanın kısıtlı olduğunu, yeniden düzenlenmesi gerektiğini belirtmişlerdir (Işık, 2001; Atbaşı, 2007; Akşit, 2011).

Bunun yanında öğretmenler ders kitaplarında şu eksiklikleri tespit etmişlerdir: Bazı konuların öğrencilerin seviyesinin üzerinde olduğu, konuların kronolojik olarak verilmesi gerektiği, siyasi konular yerine kültürel konulara ağırlık verilmesi gerektiği, etkinliklerin öğrencilerin seviyesinin üstünde olduğu, müfredatta ezberci anlayıştan vazgeçilmesi, toplumsal tarih bilinci oluşturacak içerikte olması gerektiğini belirtmişlerdir. Ayrıca konuların hikâyelerle zenginleştirilerek ilgi çekici hale getirilmesi gerektiği vurgulanmıştır.

Araştırmanın sonuçlarına bağlı olarak şu önerilerde bulunulmuştur:

1. Araştırmada Sosyal Bilgiler dersi ile öğrencilere verilecek değer kazanımlarının şunlar olduğu belirlenmiştir: Yardımlaşma, hoşgörü, evrensel değerler, insan hakları, saygı sevgi, eşitlik, özgürlük ve ahlaki değerler, sorumluluk bilincine sahip olma, vatan ve milletine bağlı olma, günümüz ve geleceği daha iyi yorumlama becerisi, tarih bilincidir. $\mathrm{Bu}$ değerlere öncelikli olarak öğretim programında yeterli oranda yer verilmesi önerilmektedir.

2. Tarihi kahramanlar önemli değerleri üzerlerinde taşırlar. Değer eğitiminde tarihte önemli işler yapmış kişiler anlatılarak öğrencilerin onları 
örnek almaları sağlanabilir. Bunun için de değer eğitimi konularıyla öğretim programı ve ders kitapları zenginleştirilerek bu konulara daha fazla yer verebilir.

3. Araştırmada ders saatlerinin yetersiz olması; konuların yetiştirilememesi, yüzeysel anlatılması, öğrenciler tarafından akılda tutulamaması, öğrencilere fazla söz hakkı verilememesi, farklı ölçme değerlendirme metotlarının kullanılamaması gibi sonuçları ortaya çıkmıştır. $\mathrm{Bu}$ sonuçlara göre, ders saatlerinin sayısı arttırılması veya öğretim programının kapsamının daraltılması önerilmektedir.

4. Araştırmada 5. sinıflarda Atatürk ilkeleri konusundaki kavramların öğrenciler tarafından anlaşılmadığı ortaya çıkmıştır. Buna göre, ilgili konuların daha sonraki sınıfların programına konulması önerilmektedir.

5. Araştırmada 7. sınıflarda Osmanlı tarihi konuları çok geniş ve birbirinden kopuk, konu akışı ders işlenişini etkilediği ortaya çıkmıştır. Buna göre, ortaokul 7. sınıf tarih konuları olayların oluş sırasına (kronolojik) göre verilmesi önerilmektedir.

6. Araştırmada 8. sinıflarda işlenen İnkılap Tarihi ve Atatürkçülük dersi konularının çok geniş olduğu ve ayrılan sürede yetiştirilemediği görülmüştür. Çoğu öğretmen vatandaşlık dersinde inkılap tarihi konuları işlemektedir. Ortaokul 8. Sınıf İnkılap Tarihi ve Atatürkçülük dersinin saatleri artırılabilir veya öğretim programının kapsamı daraltılabilir.

\section{Kaynakça}

Akşit, İ. (2011). İlköğretimde görev yapan sosyal bilgiler öğretmenlerinin sosyal bilgiler öğretiminde karşılaştıkları sorunlar (Denizli- Erzurum Örneği). Yayınlanmamış yüksek lisans tezi. Pamukkale Üniversitesi Sosyal Bilimler Enstitüsü, Denizli.

Atbaşı, C. (2007). Illköğretim II. kademe (6. ve 7. sinffta) sosyal bilgiler dersinin öğretimi ve öğretiminde yaşanan güçlükler (Aksaray örneği). Yayınlanmamış yüksek lisans tezi. Selçuk Üniversitesi Sosyal Bilimler Enstitüsü, Konya.

Başc1, Z. (2012). Beşinci slmıf sosyal bilgiler dersinde değer eğitiminin öğretmen görüşlerine göre incelenmesi (Erzurum örneği). Yayınlanmamış doktora tezi. Atatürk Üniversitesi Eğitim Bilimleri Enstitüsü, Erzurum.

Bulut, İ. (2006). Yeni İlköğretim Birinci Kademe Programlarının Uygulamadaki Etkililiğinin Değerlendirilmesi. Yayınlanmamış doktora tezi. Fırat Üniversitesi Sosyal Bilimler Enstitüsü, Elazığ. 
Creswell, J. W. (2003). Research Design: Qualitative, Quantitative and Mixed Methods Approache. California: Sage Publication.

Creswell, J. W. (2005). Educational research. planning, conducting and evaluating quantitative and qualitative research. New Jersey: Pearson Education.

Creswell, J. W., Hanson, W. E., Plano, V.L.C., \& Morales, A. (2007). Qualitative research designs selection and implementation. The Counseling Psychologist, 35 (2), 236-264.

Demircioğlu, İ. H. (2005). Tarih öğretiminde öğrenci merkezli yaklaşımlar. Ankara: Anı Yayınları.

Demircioğlu, İ. H. (2006). Avrupa birliği ülkeleri ve Türkiye'de tarih öğretiminin genel amaçlarının karşılaştırmalı bir değerlendirmesi. Firat Üniversitesi Sosyal Bilimler Dergisi, 16 (2), 133-146

Deveci, H. ve Ay, T. S. (2009). İlköğretim öğrencilerinin günlüklerine göre günlük yaşamda değerler. Uluslararası Sosyal Araştırmalar Dergisi, 2 (6), 167-181.

Doğanay, A., \& Sarı, M. (2008). Öğretmen gözüyle yeni sosyal bilgiler programı: Adana ilinde bir araştırma. Ilköğretim Online, 7 (2), 468-484

Erden, M. (1996). Sosyal bilgiler öğretimi (6. Baskı), Ankara: Alkım Yayınevi.

Farmer, A. \& Knight, P. (1995). Active history in key stages. London: David Fulton Publishers.

Güler, İ. (2005). Tarihin toplumdaki işlevi ve öğretimi. İstanbul: Elif Kitabevi.

Haaberli, P. (2005). Relating to History: an Empirical Typology. http://www.heirnet.org/IJHLTR/journal9/papers/haeberli.pdf.

(Erişim Tarihi: 8 Ekim 2014).

Hürsen, Ç. ve Uzunboylu, H. (2008). İlköğretim 4. ve 5. Sınıf Sosyal Bilgiler Öğretim Programının Öğretmen Görüşlerine Göre Değerlendirilmesi. VIII. International Educational Technology Conference. 6-9 Mayıs 2008, Eskişehir.

Işık, Y. (2001). Illköğretim 4. ve 5. sinıf sosyal bilgiler programının sinıf ortamında öğretilmesinde karşılaşılan güçlüklerle ilgili uzman, müfettiş ve öğretmen görüşleri. Yayınlanmamış yüksek lisans tezi. Hacettepe Üniversitesi Sosyal Bilimler Enstitüsü, Ankara.

Leech, N.L. \& Onwuegbuzie, A.J. (2009). A typology of mixed methods research designs. Quality \& Quantity, 43 (2), 265-275.

MEB. (2006). Illköğretim sosyal bilgiler 5. sınıf öğretmen kılavuz kitabı (2. Baskı). Ankara: Saray Matbaacilık.

Morgan, D. L. (1998). Practical strategies for combining qualitative and quantitative methods: Applications to health research. Qualitative Health Research, 8 (3), 362-376. 
National Commissionn of Social Studies NCSS (1993). A vision of powerful teaching andlearning in the social studies: building social understanding and civic efficacy. Social Education, 57 (5), 213-223.

Onwuegbuzie, A. J. ve Johnson, R. B. (2006). The Validity Issue in Mixed Research. Research In The Schools. Mid-South Educational Research Association, 13 (1), 48-63.

Onwuegbuzie, A.J. \& Johnson, R.B. (2004). Mixed methods research: a research paradigm whose time has come. American Educational Research, 33 (7), 14-26.

Özbaran, S. (1998). Neden ve nasıl tarih?, (Editör: S. Özbaran) Tarih Öğretimi ve Ders Kitapları. (s. 25-33). İzmir: Dokuz Eylül Yayınları.

Paksoy, A. (1997). Eğitimde birlik ve tarih öğretimi. Abece Dergisi, 133, 12

Polat, L. (2012). İlköğretim 6. sinıf sosyal bilgiler dersi öğretim programının genel amaçlarına ulaşma düzeyine ilişkin öğretmen görüşleri (Elazı̆̆ ili örneği). Yayınlanmamış yüksek lisans tezi. Fırat Üniversitesi Eğitim Bilimleri Enstitüsü, Elazı ğ.

Tekeli, İ. (1998a). Küreselleşen dünyada tarih öğretiminin amaçları ne olabilir, (Editör: S. Özbaran) Tarih öğretimi ve ders kitapları. (s. 35-43), İzmir: Dokuz Eylül Yayınları.

Tekeli, İ. (1998b). Tarih bilinci ve gençlik. İstanbul: Tarih Vakfı Yurt Yayınları.

Tokdemir, M. A. (2007). Tarih öğretmenlerinin değerler ve değer eğitimi hakkındaki görüşleri. Yayımlanmamış yüksek lisans tezi. Karadeniz Teknik Üniversitesi Sosyal Bilimler Enstitüsü, Trabzon.

Tunçay, M. (1998). Tarih öğretiminin iyileştirilmesine yönelik düşünceler, (Editör: S. Özbaran) Tarih öğretimi ve ders kitapları. (s. 55-57). İzmir: Dokuz Eylül Yayınları.

Uçar, S. (2009). Sosyal Bilgiler programındaki değerlerle ilgili kazanımlara yönelik öğretmen görüşlerinin değerlendirilmesi. Yayımlanmamış yüksek lisans tezi. Çukurova Üniversitesi Sosyal Bilimler Enstitüsü, Adana.

Vedder, P. \& Veugelers, W. (2003). Values in teaching. Teachers and Teaching: Theory and Practice, 9 (4), 377-388.

Yalar, T. (2010). Illköğretim sosyal bilgiler programında değerler eğitiminin mevcut durumunun belirlenmesi ve öğretmenlere yönelik bir program modülü geliştirme. Yayınlanmamış doktora tezi. Mersin Üniversitesi Sosyal Bilimler Enstitüsü, Mersin.

Yanpar, Ş. T. (1997). İlköğretimde sosyal bilgiler derslerinde karşılaşılan sorunlar ve çözüm önerileri. Çă̆daş Eğitim Dergisi, 22 (231), 41-43.

Yazıcıoğlu, Y. ve Erdoğan, S. (2004). SPSS uygulamalı bilimsel araştırma yöntemleri. Ankara: Detay Yayıncılık. 
Sosyal Bilimler Dergisi 379

Yiğittir, S. ve Öcal, A. (2011). Lise tarih öğretmenlerinin değerler ve değerler eğitimi konusundaki görüssleri. KMÜ Sosyal ve Ekonomik Araştırmalar Dergisi, 13 (20) 117-124. 